\title{
Det lyriske epos
}

\section{- en "ny" genre i moderne fransk litteratur}

\author{
AdAM Ægidius
}

Modernistisk poesi er karakteriseret ved tekster, der leger med genreoverskridelser og -blandinger, og som ofte opfattes som provokerende og traditionsbrydende, som om de ikke tilhørte én bestemt genre, men derimod var genreløse. Teksterne læses sjældent ud fra de nye genrenormer, de rent faktisk indstifter.

I denne artikel vil jeg forsøge at placere en række modernistiske tekster i en genre, jeg vil kalde for det lyriske epos (cf. litteraturlisten). Som det vil fremgå, mener jeg, genrekonstruktion bunder i komplekse forbindelser mellem tekster, forfattere, litteraturhistorie, intertekstualitet, m.m. Teksterne, der er skrevet af prominente digtere fra det $19.0 \mathrm{o} 20$. århundredes franske litteratur, har været underkastet mange forskellige analyser. Problemet er, at kritikernes sporadiske genreovervejelser ikke har givet anledning til en mere omfattende undersøgelse af genren som sådan.

Victor Hugos mesterværk La Légende des siècles (I859) er givetvis det første markante værk i genren. Værket - 750 sider på rimede vers - er bygget op af “små epopéer" (værkets første titel), der udgør afsluttede fortællinger. De eksemplificerer hver sin historiske periode, som i løbet af værket sættes sammen til en storslået beretning om menneskeheden fra tidernes morgen til dommedag. Værkets ambition, skriver Hugo, er

at beskrive menneskeheden diakronisk og synkronisk $i$ alle dens aspekter, gennem historien, fabler, filosofi, religion og videnskab, hvilket kan sammenfattes i én eneste umådelig bevægelse frem mod lyset (Hugo I950: 3 ). ${ }^{\mathrm{I}}$
Dermed bryder han med en lang episk tradition i Frankrig, idet eposet bliver "flerfoldigt", "demokratisk” og “diskontinuert” (Millet I995: 27).

\section{En "falsk" epiclesis}

Det lyriske epos har flere af det klassiske epos' kompositoriske træk. Det er som regel bygget op af nummererede sange eller episoder, som ikke kan eller skal læses som autonome digte. Valery Larbaud gjorde opmærksom på dette $\mathrm{i}$ forbindelse med en forespørgsel om at publicere dele af Saint-John Perses Anabasis:

Man kan ikke udelade nogen del af digtet: det skal enten udgives samlet eller slet ikke udgives. Derfor kan der ikke blive tale om at publicere et fragment af det i tidsskriftet 'Intentioner' (Larbaud I99I: I43).

Det lyriske epos er således ikke en digtsamling, men derimod et organisk værk, der kræver en kronologisk læsning. Denne organiske værkopfattelse kan henføres til forfatternes intentioner: Claudel ønsker $\mathrm{fx}$ at skabe en "cyklus af sange", han er "træt af fragmentariske værker", og han ønsker at "skabe et helhedsværk over en længere årrække” (Claudel 1967: p. I09of).

Et klassisk epos begynder med, at digteren henvender sig til sin muse eller en guddom for at bede om hjælp til at komme godt igennem sit store værk (Brunel 2003: 196). Denne kompositionelle dedikationsfigur kaldes på græsk for en epiclesis. I det lyriske epos transformeres brugen af denne figur. I Sømarker (fransk: Amers, 1957) påkalder digteren hverken en muse eller en guddom, men derimod 
havet som sin ledsager. Ifølge Brunel stammer denne påkaldelse snarere fra oden end fra det klassiske epos, og den bliver derfor til en "falsk" epiclesis (Brunel 2003: 196). Når Sømarker i sin helhed er et epos, men låner påkaldelsen fra oden, får det status af et "falsk epos" (p. 200f), der har sine rødder i den lyriske tradition.

Idet digteren i Sømcerker hylder havet og ikke guddommen, bliver den "falske" epiclesis profan. Denne simple, men oprigtige hyldest af kosmos udvikler sig endvidere til en regulær komplementaritet mellem poesien og kosmos:

Poesi for at akkompagnere rytmen i en recitation til ære for Havet.

Poesi for at assistere sangen til en vandring rundt $i$ omkredsen af Havet. [...]

Og det er en sang for havet som den aldrig er blevet sunget, og det er Havet $\mathrm{i}$ os der vil synge den (Saint-John Perse 2003: I5).

Hugos La Légende des siècles indledes på lignende vis med sangen "Visionen, som denne bog stammer fra", hvor digterinstansen forklarer, at han "havde en drøm, hvor århundredernes mur tonede frem" (Hugo 1950: 8). Denne drøm bliver udgangspunkt for digterens intention om at fortælle "menneskets bitre, umådelige og sammenstyrtede epos” (p. I4).

Denne "falske" epiclesis henvender sig heller ikke til musen eller en guddom, men gør opmærksom på, at selve det værk, læseren stilles overfor, har været en konkret arbejdsproces, hvor bevægelsen fra idé til udførelse har krævet en stor indsats. Selvom Gud nævnes, er Hugos "falske" epiclesis moderne, fordi det er digteren selv, som ansvaret for værket overdrages til, og som dermed lovprises. Denne "falske" epiclesis $\mathrm{i}$ form af den metapoetiske hyldest findes også hos Aragon (1963: I6ff), Glissant (1985: 169) og Alyn (I968: 45; 2002: 42), hos de to sidstnævnte endda med samme dedikation til havet.

\section{En legendarisk verdensanskuelse}

Leconte de Lisles Poèmes barbares (I862) er ligesom Hugos La Légende des siècles opbygget af "små epopéer”, som genfortæller historie- og legendestof.
Leconte de Lisle inspireres af den nordiske mytologi, når han fx gendigter "Legenden om nornerne", som er et led i Leconte de Lisles omfattende skabelsesberetning. Legenden peger dog proleptisk frem mod værkets næstsidste miniatureepos, "Menneskets udslettelse", for nornerne siger, at "timen er nær", hvor menneskets livsånde vil slukkes (Leconte de Lisle 1935: 55). Som hos Hugo skaber Leconte de Lisle en kronologisk progression fra menneskets mytehistoriske oprindelse i tidernes morgen til den dag, hvor mennesket ikke længere eksisterer.

Også Victor Hugo var inspireret af nordisk mytologi og historie. Han tager $i$ en af sine "små epopéer" i La Légende des siècles udgangspunkt i det afsnit af danmarkshistorien, der handler om Knud d. Store (IOI4-35). Faderen, Sven Tveskæg, døde under mystiske omstændigheder, der gav næring til mange rygter og spekulationer. Ifølge Jacques Truchet, der har redigeret Hugos samlede værker, var det en udbredt opfattelse, at Sven Tveskæg blev slået ihjel af en ukendt gerningsmand (Hugo I950: II67). I Hugos lyriske epos er det imidlertid Knud selv, der dræber sin far. Efter sin død, og efter at Århus' biskop under begravelsesceremonien erklærer ham for "hellig" (p. 136), straffes Knud for fadermordet, idet han i det hinsides rammes af en konstant regn af bloddråber. Således udnytter Hugo huller i historien og skaber en legende på grundlag af rygtedannelse, men uden at fortællingen bliver usandsynlig. Ved at levere en morale og fabulere over Knuds skæbne i det hinsides mytificerer han historien. En legende - jævnfør titlen La Légende des siècles - består netop $\mathrm{i}$ en "historisering af en myte og en mytificering af Historien" (Millet 1997: II8). Det er denne legendariske verdensanskuelse, som det moderne lyriske epos gør til sit episke omdrejningspunkt.

Efter Hugo og Leconte de Lisle forsvinder de "små epopéer" med de afsluttede fortællinger fra det lyriske epos. Også i de efterfølgende lyriske eposer refereres der til historien, myter og legender, men på en anden måde. Péguy henviser fx til Jeanne d'Arc, Sainte Geneviève og korstogene i middelalderen, men han gør det for at drage en parallel til samtiden (første verdenskrig). Historien bliver blot 
et spejl for en særlig sindstilstand eller for moralske og religiøse problematikker, der udfoldes i lange lyriske passager med kun få egentlige begivenheder. Det episke fungerer altså udelukkende som en overordnet ramme for værket. Det fremtræder symbolsk eller i fragmenter og får aldrig status af en narrativ udsigelse, som man kender fra Odysseen eller Rolandskvadet.

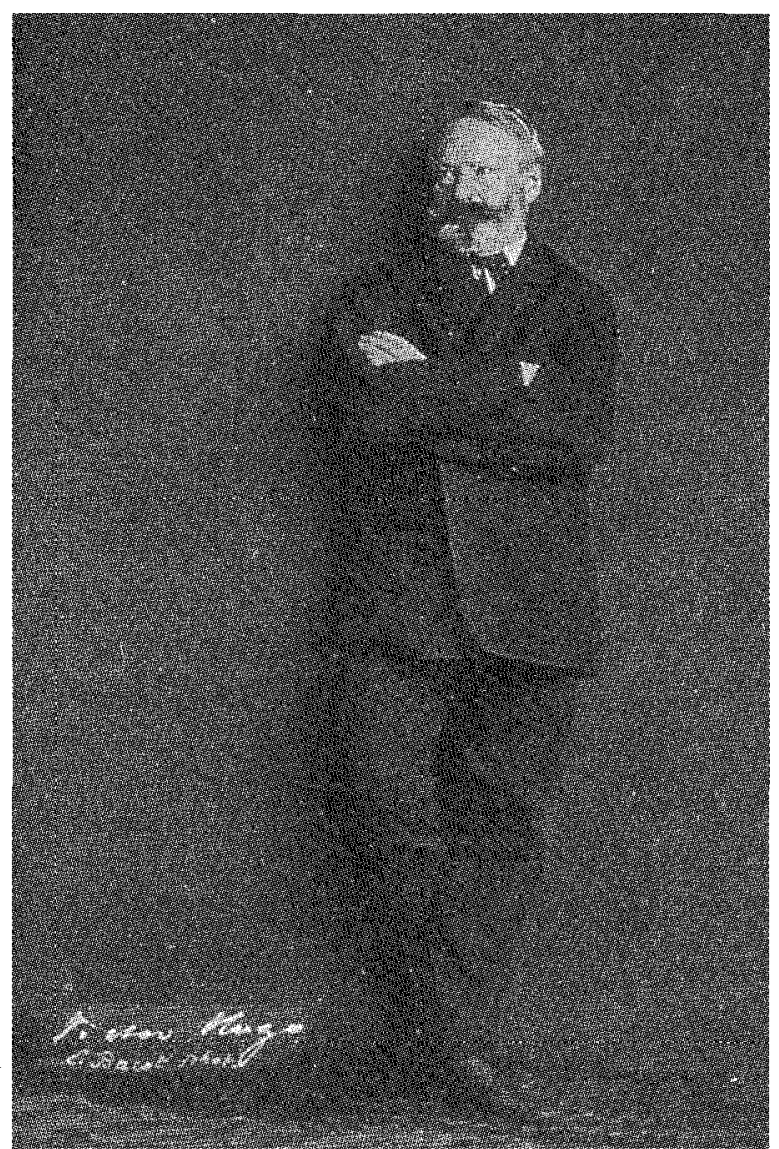

Victor Hugo

\section{Heroisme}

Det klassiske epos er en kronologisk beretning om en ophøjet heroisk dåd, som ofte er bedrevet under en krig. Da en krig etablerer klare grænser mellem to folkeslag, er eposet udtryk for en partisk udlægning af en krigshandling (Brunel 2003: 143) og kan på denne måde siges at konstituere et folks selvforståelse. Dette heroiske og nationalistiske aspekt går ikke tabt i det lyriske epos. Hugo, der på udgivelsestidspunktet er i politisk eksil, tilegner Frankrig $\mathrm{La}$ Légende des siècles (Hugo I950: I), Péguy dyrker franske helgener og heltinder. I Claudels Feuilles de Saints (I925), der som titlen angiver handler om franske helgener, er episoden "Sainte Geneviève" en klar henvisning til første verdenskrig. Sainte Geneviève, Paris' skytshelgen, reddede i år 45I Paris fra hunnernes invasion. Ifølge Claudel er det også hende, der i 1918 atter redder pariserne fra undergang (Claudel 1967: I139). Når Claudel skriver: "Prøv at se linien derhenne mellem træerne, Geneviève, dér, hvor Barbarerne vil dukke op" (Claudel 1967: 637), skal "Barbarerne" opfattes som de tyskere, der ligesom hunnerne i tidernes morgen angriber Frankrig. Claudels nationalisme er stærk, og krigen, som er kernen i det klassiske epos, indgår således også i det moderne lyriske epos.

I det lyriske epos er det imidlertid ikke kun heroer og helgener, der besynges. Der sker også en kanonisering af selve digterslægten. I Fenilles de Saints kanoniserer Claudel egenhændigt Paul Verlaine og Jacques Rivière (1967: 599ff; 690), uden tvivl fordi de begge er lige så stærkt optaget af den katolske tro som han selv. I La Légende des siècles hylder Hugo Vergil, Dante, Petrarca, Ronsard, Voltaire, Diderot, m.fl. Og Aragon hylder i Les Poètes (Aragon 1969: I32) nogle af de digtere, som han mener, har lidt martyrdøden for poesiens skyld: Desnos, der døde i en koncentrationslejr, Majakovski, der begik selvmord, Lorca, der blev myrdet under Den spanske Borgerkrig, Apollinaire, der blev ramt af en granat under første verdenskrig og døde af sine kvæstelser. Det lyriske epos skaber således intet mindre end alle tiders digtergenealogi.

\section{Det eksotiske som poetisk modus}

Ligesom det klassiske epos (Illiaden eller Rolandskvadet) fremstår det lyriske epos som et sammenstød mellem den vestlige og den orientalske kultur. Den geografiske distance fra det velkendte skaber en eksotisme og etablerer en fremmedhed i forhold til den kultur eller det folk, som synsvinklen lægges hos. Aragons Le Fou d'Elsa (1963) drejer sig om de kristnes tilbageerobring af Granada sidst i I400-tallet, 
hvor maurerne drives på flugt. Aragon lægger synsvinklen hos de muslimske maurere, der kæmper mod den kristne overmagt, og han kritiserer kristendommen og det vestlige samfund med en allegorisk reference til det kapitalistiske samfund, som kommunisten Aragon også lægger afstand til i det virkelige liv. For Aragon (1963: 13) er Granadas fald lige så vigtigt som Trojas fald, som jo er 1lliadens omdrejningspunkt, men som også er hovedinspirationskilde i både det klassiske franske epos og i Aragons og Saint-John Perses moderne lyriske eposer (cf. Rigolot 1987: I07).

Det lyriske epos rummer ligesom det klassiske epos mange eksotiske elementer. I Orientalism (1978) fremsætter Edward Said den tese, at orientalismen som begreb er en vestlig konswuktion. Han mener, at orientalismen er en særlig diskurs, som vesterlændinge fører om et ganske stort geografisk område, der er særdeles heterogent på sociale, politiske og religiøse felter (Said I995: 50). Victor Hugo har ifølge Said forfattet tekster om Orienten uden nogensinde at have sat sine ben i denne verdensdel, men ved blot at læse bøger om den (p. 82f). Idéen om det orientalske skabes således rent tekstuelt, og det orientalske kommer til at fremstå som en "metafor" eller en særlig "tankegang” (p. IOI). Forskellen på at have læst om Orienten og selv at have været der kommer tydeligt til udtryk i dette citat af den vidt berejste Nerval:

For en person, som aldrig har set Orienten, [...] er en lotusblomst stadig en lotusblomst. For mig er den ikke andet end et slags løg (citeret p. IоI).

Saint-John Perse har ligesom Nerval afvist denne form for orientalisme i sine værker. Det ændrer imidlertid ikke ved det forhold, at man i fx Sømarker konstant fornemmer netop en orientalisme! Perse er tydeligvis fascineret af eksotisk flora og fauna, samt af orientalske historiske, mytologiske og religiøse motiver. Hvis man skal søge et kompromis mellem det, at man opfatter eksotiske elementer i hans værker, og hans pure afvisning af dette, kunne man tale om det eksotiske som en poetisk modus. I den forbindelse kan man nævne en forfatter som Victor Segalen, der har samme opfattelse af orientalismen som
Saint-John Perse. I sit Essai sur l'exotisme plæderer han for en opfattelse af orientalismen, der modstrider vestens diskurskonstruktion. Han kalder denne form for orientalisme for "andethedens æstetik" og forbinder den med "det fremmede, det uhørte, det uventede, det overraskende, det mystiske, kærligheden, det overmenneskelige, det heroiske og endda det guddommelige" (Segalen 1978: 82). Opfattet som en "æstetik" bliver det eksotiske forankret rent tekstuelt i den poetiske tekst:

Og dette er timen, oh levende kvinder! hvor brisen fra havet opgiver sin chance for den sidste indånding fra landjorden. Træet belagt med ringe, ligesom en slave, åbner sit brusende løvspring. Vore gæster farer vild på skråningerne under deres eftersøgning af spor pegende mod havet, kvinderne på eftersøgning af lavendel, og vi selv, vi renser os i aftenens afvaskning... Ingen trussel på aftenens pande, anden end denne store himmel af hav med sneuglens hvidhed. Måne af pebermynte $i$ Orienten. Rød stjerne forneden på himlen, ligesom avlshingsten der har smagt salt. Og manden fra havet findes i vore drømme. Den bedste blandt mænd, kom og tag! (Saint-John Perse 2003: 88f).

Det eksotiske som poetisk modus består i et ordvalg, der er forbundet med fjerne, geografiske områder ("sneugle" og "Orienten"), sammenligninger, hvis domæner ligger fjernt fra hinanden, således at der opnås en fremmedgørende effekt på læseren ("ligesom avlshingsten der har smagt salt"), suggestive beskrivelser, der ikke giver indtryk af et sammenhængende, fænomenologisk rum, konkrete værdier sammenstilles med abstrakte værdier ("brisen fra havet opgiver sin chance"). Samspillet af disse elementer skaber selve den eksotiske effekt og den poetiske modus, der består i "andethedens æstetik".

På den ene side bevarer det lyriske epos den konfrontation mellem den vestlige og orientalske kultur, som det klassiske epos indeholder. På den anden side indskriver genren det eksotiske $\mathrm{i}$ den poetiske udsigelse, således at det eksotiske bliver en poetisk modus eller en "æstetik". Denne måde at behandle det eksotiske på udgør en genretransformation, hvor det lyriske epos tydeligt adskiller sig fra det klassiske. 


\section{En deskriptiv metafor}

Som ovenstående eksempel viser, er det poetiske sprog i det lyriske epos hyperbolsk, eklatant og farverigt, og det er ofte vanskeligt at skille narration, deskription og metaforer fra hinanden. Césaire excellerer ved at bevæge sig inden for dette uvisse paradigme:

græsset făr dønningernes lange

alkoholiske bevægelse

til at gynge for kvæget dette håbets blide skib

stjernerne $i$ deres aldrig sete rings indfatning

vil skære aftenens orgelpiber over

og vil derefter sprede

zinniaer

coryanthesorkidéer

ud over den frugtbare udkant af min træthed

(Césaire I956: 70)

Er dette uddrag en metafor eller en beskrivelse eller begge dele på samme tid? En sammenstilling af to forskellige begreber skaber altid en metaforicitet, hvis betydningen ikke er synekdokisk eller litteral som i fx "bogens sider". Derfor vil man opfatte "håbets blide skib" og "aftenens orgelpiber" som metaforer. Problemet er imidlertid, at disse metaforer ikke konceptualiserer en semantisk interpretationsramme. De visualiserer uden at generere egentlig betydning, og man kunne derfor kalde dem for deskriptive metaforer, dvs. metaforer, der har mistet deres egentlige metaforicitet. De deskriptive metaforer præsenterer de metaforiske elementer, som om de er virkelige, de insisterer på den konkrete eksistens af metaforens elementer, således at metaforiciteten bliver minimal. Der skabes med andre ord et rum, et deskriptivt univers.

Ovenstående uddrag er i sin helhed en form for beskrivelse, men det kan diskuteres, om det er muligt at forestille sig det rum og den bevægelse, som beskrivelsen iscenesætter. Denne form for beskrivelse er udtryk for det, Hugo Friedrich kalder for "sansemæssig irrealitet" (Friedrich I968: 85), nemlig en virkelighed, som skabes, men som ikke kan repræsentere den fænomenologisk konfigurerede verden, vi bevæger os i. Den sansemæssige irrealitet er mest tydelig hos Césaire, Glissant, Saint-John Perse og Alyn.

\section{Formens hybriditet}

En af de måder, det lyriske epos transformerer det klassiske epos på, kan aflæses $\mathrm{i}$ den poetiske udtryksform. Her er det tydeligt, at genren er opstået i overgangen til den modernistiske æra. Hugos La Légende des siècles (1859) er overvejende skrevet $\mathrm{i}$ klassiske aleksandrinere, men det frie vers opstår hurtigt derefter $\mathrm{i}$ fransk symbolisme. Bibelverset ("le verset”), der er en udvidelse af det frie vers, går fra to til flere linier og kan til tider være svært at skelne fra prosa. Péguy, Claudel og Saint-John Perse er blandt de første til at indføre denne form i moderne poesi i starten af r9oo-tallet. Hvor Péguy og Claudel har tydelige religiøse motiver, bruger Saint-John Perse bibelverset på grund af dets sublime karakter. Hos Saint-John Perse, Aragon, Césaire, Glissant og Alyn er der dog glidende overgange mellem rimede vers, frie vers, bibelvers og prosa, og deres tekster fremtræder $\mathrm{i}$ realiteten som hybrider mellem disse former.

De frie vers, bibelverset og prosaen burde i princippet ikke have bindinger af nogen art. Imidlertid er de $i$ det lyriske epos bundet af rytme og klangvirkninger, men uden faste metriske mønstre og rim. Bundetheden og den rytmiske afhængighed giver sig udslag $\mathrm{i}$ omvendte ordstillinger, som dem man finder $i$ rimede vers, hvor enderimets ordtvang kan påvirke versets syntaks. I det følgende frie vers “Que sais-tu du dehors toi qui n'as même pas de l'heure ou du jour certitude" (Aragon 1963: 277) ville "certitude" efter de normale syntaktiske regler placeres efter "pas". Imidlertid bliver verset rytmisk set bedre afbalanceret, når gentagelsen af de to t'er i "certitude" placeres i slutningen af sætningen. Det rytmiske hensyn skaber dermed tekstens stilniveau, der ikke får det rå hverdagspræg, som mange modernistiske tekster kultiverer $\mathrm{i}$ det 20. århundrede. Teksten bliver derimod lyrisk højstemt. Det lyriske epos giver dermed en erindring om lyrismens ophav: sangen og rytmen (Maulpoix 2000: 294). Den rytmeskabende omvendte ordsilling vidner ikke blot om, at "rytmen er selve tankens bevægelse", 
som Emile Verhaeren har udtrykt det (Marinetti 1909: 35). Den er også et specifikt genretræk.

\section{Det stratificerede lyriske subjekt}

Det er en almindelig opfattelse, at det lyriske subjekt er den, der taler i teksten, den, der eksplicit siger "jeg". Det lyriske subjekt er dog langt mere komplekst: Det taler gennem utallige instanser og er symboliseret ved forskellige figurer, som det agerer igennem. Man kan sige, at det er stratificeret.

I Saint-John Perses tekster, navnlig i Exil, forekommer der ofte citerede ytringer, hvor der ikke står eksplicit, hvem der er ansvarlig for dem, men hvor læseren slutter, at det er fortælleren, der går i dialog med sig selv. Det lyriske subjekt stratificeres således $\mathrm{i}$ flere forskellige udsigelsespositioner (jeget inden i citationstegnene og jeget uden for dem). At der er tale om det samme subjekt, understreges af, at de forskellige instanser bruger de samme ord og den samme stil. Det samme gælder i de tilfælde, hvor de talende subjekter er navngivne. De lyriske udsigelsesinstanser har med andre ord ikke samme grad af selvstændighed som en romanperson.

Det lyriske subjekt er symboliseret ved figurer som "Prinsen" (p. 97), "Den Fremmede" (p. IOI), "Shamanen" (p. I8I), "Hyrden" (p. I84), "Digteren" (p. 193), hvorved det tilføres en mytisk, naiv og ophøjet karakter. Undertiden sammensmeltes det symbolske plan med udsigelsesplanet: Når "Troldmanden går hen til sin tids mennesker $\mathrm{i}$ gader og stræder iført dagligdagstøj”, er det "måske en morgen magen til denne" (p. 189). Her er "Troldmanden" symbol på digteren. Udsigelsesinstansen er knyttet til tekstens deiksis, der etablerer tekstens tid ("en morgen"), sted og modaliteter ("måske") og konfigurerer deres indbyrdes relationer i forhold til den talendes jeg-her-nu-situation (“denne"). Der gives således mulighed for, at den talende, altså udsigelsesinstansen, overværer troldmandens passeren.

Analogien mellem "Troldmanden" og udsigelsesinstansen antyder, at udsigelsesinstansen faktisk inkarnerer denne troldmand. Symboliseringen bliver et billede på udsigelsesinstansen, der projicerer sig selv over på konkrete instanser. Det lyriske subjekt er derfor en kombination af symboliseringer og udsigelsesinstansens stratificerede stemmer.

Stratificeringen af det lyriske subjekt understreges desuden af brugen af prosopopoiaen. Denne stilfigur, der tildeler dyr, ting, begreber og fraværende eller døde mennesker en stemme, bruges hyppigt hos Hugo, Péguy og Claudel, hvor orme, havet, Gud og Dante taler. Det er dog tydeligt, at det lyriske subjekt taler gennem disse stemmer. I "Ormens epopé", der er en morbid skildring af livets forgængelighed, taler ormen gennem en prosopopoia. Dens magt består $\mathrm{i}$ at tilintetgøre alt levende efter dets død ved at omdanne det til muldjord. Man kan sige, at det lyriske subjekt taler gennem ormen, idet det samme kyniske grundsyn som i resten af $L a$ Légende des siècles kan spores $\mathrm{i}$ ormens holdninger, nemlig det at al social rang og det dennesides er underordnet Guds straf og skæbnens ironi:

Helten tror, han efterlader et glorværdigt slør over sin grav, Efter at han har dikteret historiens gang,

Men det eneste, han kan være sikker på,

Er, at han ender her hos mig.

Det er min skyld, at mennesket fortvivler.

Jeg ser sønnen blive født, og jeg venter på faderen,

Mens jeg fortærer bedstefaderen (p. 20I).

I den efterfølgende episode, "Digteren til ormen", lægger digteren afstand til ormens kyniske indstilling. Dette ændrer dog ikke ved det faktum, at det lyriske subjekt kan tillægges ansvaret for både ormens og digterens holdninger. Den sidste episode fremtræder netop, som om digteren ved, at læseren ved, at digteren udtrykker sine holdninger gennem ormens tale. Og når ormens grundsyn er gennemtrængt af så brutal en kynisme, må digteren delvist tage sine ord i sig igen for ikke at blive stemplet som hensynsløs.

Den stratificerede identitet angiver det lyriske subjekts alteritet, således at den, der $\mathrm{i}$ traditionel forstand siger "jeg" i digtet, ikke har nogen "central kerne" (Maulpoix 1996: I5I), men derimod taler og handler gennem andre. Det lyriske subjekt er således ikke en konkret instans, man kan pege på, men inkarnerer selve teksten. Det lyriske subjekt er summen af 
tekstens elementer, af dens figurer og dens udsigelse. Det består også i en permanent identitetssøgen, en proces, hvor subjektet stiller spørgsmål til sig selv, verden og tilværelsen (Rabaté I996: 66), og som går via det at tale gennem andre instanser og derigennem afprøve sin identitet. Digteren eller udsigelsesinstansen står uforstående over for sig selv og forundres over sine poetiske evner, som når han $\mathrm{fx} i$ Perses Exil siger:

Og hvem er det dog, der her i nat på mine fremmede læber mod min vilje har påbegyndt denne sang? (Saint-John Perse I982: I28).

\section{Prosentativets ontologiske status}

Behovet for identitet manifesterer sig i det lyriske epos $i$ en særlig poetisk udsigelseskonfiguration, præsentativet. Et præsentativ er en konstruktion, man bruger til at introducere nye informationer (rhema) i diskursen (cf. Rabatel 200I). På fransk bruger man c'est (det er), il $\gamma$ a (der er) og voici/voilà (her er). I Saint-John Perses Krønike bruger fortælleren præsentativet til at forsøge at fastholde en identitet, og når fortælleren hyppigt siger: "Her er jeg..." (Me voici eller Nous voici), aktualiserer han sin tilstedeværelse. Præsentativet, som i det lyriske epos oftest forekommer i præsens, indskriver det lyriske subjekt eller andre udsigelsesinstanser i udsigelsens her og nu. Selve det at udtale ordene stadfæster fortællerens eksistens. At han bliver nødt til permanent at gentage disse ord, peger på, at han forst finder sin identitet, når han påkalder sig den ved hjælp af talen.

Præsentativet har dog også en anden specifikt poetisk udsigelse. Det optræder undertiden i særlige konfigurationer, hvor det gentages excessivt, her hos Aragon:

Der er unge mennesker med hyacintøjne ude i marken

Der er hofmænd, der er klar til at gribe daggryet eller en orkan for at lave et skærf deraf til fyrsten

Der er mennesker, der har brugt så mange dage på at polere deres ord, at de længe har været umulige at opnå enighed med

Der er mennesker, der forundres af enhver blomstrende lyd, der kommer fra dem selv

Der er rejsende, der har sat sig ned for at få inspiration uden at blive grebet af den

Der er besatte mennesker, der ikke længere vasker sig, og som derfor har mistet retten til at bede

Der er sangere, der er så grimme, at de venter på, at en forbipasserende skal give deres digte en uslings legemsbygning

Der er kvinder, hvis hænder og fødder er farvede

Der er sindssyge mennesker, der siger ting, de ikke selv forstår. (Aragon 1963: 25)

Præsentativets tekstlingvistiske funktion er som beskrevet at introducere nye elementer i diskursen. Når præsentativet gentages som ovenfor, introduceres der nye elementer i hver eneste sætning. De introducerede elementer udfoldes ikke som et tema, der kan elaboreres (dvs. som en klassisk tema-rhemakonstruktion, hvor man går fra det ukendte til det kendte), men forbliver rhematiserede, således at man i hver sætning præsenteres for ny information. Dette fremkalder en minimal tekstkohæsion, hvor hver ytring får lov til at stå alene. Konfigurationen indskriver sig $\mathrm{i}$ sin helhed heller ikke $\mathrm{i}$ et større tekstsegment, der kan skabe en kohæsion mellem konfigurationen og resten af teksten.

I denne poetiske udsigelseskonfiguration introducerer præsentativet nogle elementer, hvis eneste funktion er, at de har eksistens. På grund af den minimale kohæsion fremkaldes der ikke et mimetisk rum, som er fælles for ytringerne. Hver enkelt ytring fremkalder derimod sit eget unikke univers. På den måde kan man sige, at præsentativet $\mathrm{i}$ disse konfigurationer tildeler eksistens til noget i kraft af, at det bliver sprogliggjort. Fænomenerne tildeles en egeneksistens, for opremsningen sættes ikke ind i en narrativ eller mimetisk kontekst. Præsentativet får dermed en ontologisk status. Man kan sige, at præsentativet er den sproglige manifestering af, at poesiens væsen ifølge Saint-John Perse er ontologisk: "Poesien undersøger væren! For al poetisk produktion er ontologisk" (I982: 453).

\section{Genrestilistikkens force}

Med hensyn til de nationalistiske, heroiske og eksotiske temaer lægger det lyriske epos sig som nævnt tæt op ad det klassiske epos. Forskellen, der gør det muligt at tale om to forskellige genrer, ligger i tek- 
sternes udsigelse. De ovenstående analyser af specifikke stilistiske træk er generelle for det lyriske epos. Den analysemetode, jeg har anvendt, kan man kalde for "genrestilistik". I en artikel i Langue française plæderer Dominique Combe netop for eksistensen af denne disciplin. Han undrer sig over, at interessen for stilistik og genrer hver for sig er øget uden at nogen har forsøgt at tænke disse to domæner sammen (Combe 2002: 33). Man finder dog flere sporadiske forsøg på at skabe denne "hybride" disciplin, hvor de russiske formalister, Bakhtin, Bally, Pierre Larthomas m.tl. har været foregangsmænd.

"Genrestilistikken" beror på en kompleks korrelation mellem langue og parole (Saussure), primær- og sekundærgenrer (Bakhtin), de litterære genrer som "dynamiske konstruktioner" i et historisk system samt de singulære værker (Combe 2002: 46). Korrelationen mellem disse fænomener gør det muligt at opfatte et stilistisk mønster $i$ en specifik genre. Men hvilke stilistiske træk er væsentlige? Komplekse tekster indeholder jo mangfoldige stiltræk! Combe griber til Jakobsons teori om dominanten, der går ud på, at de dominerende stiltræk i én eller flere tekster er genreskabende, og at disse derfor vil springe $i$ øjnene. Når dominanterne ændrer sig, transformeres genren. Dominanterne har indflydelse på litterturhistoriske forandringer.

Det lyriske epos har wansformeret det klassiske epos ved, at genrens dominanter har ændret form. Overgangen fra epiclesis til en "falsk" epiclesis og videre til en metapoetisk hyldest demonstrerer en sådan transformation. Det samme gælder overgangen fra vers til en hybriditet af vers, frie vers, bibelvers og prosa. Det eksotiske går fra at være bestemt af vestens diskurskonstruktion til i det lyriske epos også at være en poetisk modus indskrevet $\mathrm{i}$ selve udsigelsen. Præsentativets poetiske udsigelseskonfiguration, den minimale kohæsion og den deskriptive metafor transformerer ikke hver sin dominant, men indstifter derimod nogle radikalt nye $i$ genren.

\section{Biografisk genealogi}

Genrestilistikken kræver dog visse forbehold. En stilistisk dominant, der er fælles for to eller flere tek- ster, skaber ikke nødvendigvis en genre. Selvom genrestilistikken opfatter genrerne som dynamiske, kan metoden virke som en mekanisk konstruktion, som kritikeren kunstigt fremkalder af sammenlignende tekstanalyser. Todorov har kaldt denne form for genrekonstruktioner for "teoretiske genrer" (I970: I8). Dermed mener han genrer, som ikke har eksisteret på forfatternes tid, og som forfatterne hverken har forholdt sig til eller været bevidste om. Som eksempel herpå kan gives de middelaldertekster, som kun eftertiden har opfattet som genrer, såsom "det heroiske epos" (Schaeffer 1986: I87ff).

De "historiske genrer" indskriver sig derimod $i$ forfatternes horisont som etablerede genrer, eksemplificeret ved sonetten, eposet eller den klassiske tragedie, dvs. genrer, som er navngivne og alment udbredte på det tidspunkt, hvor forfatterne skriver.

Det lyriske epos er uden tvivl en "teoretisk" genrekonstruktion. Meget tyder dog på, at genren har været på vej til at blive "historisk". Digternes bekendtskaber og møder med hinanden i det virkelige liv (biografisk genealogi) og deres eksplicitte henvisninger til hinandens forfatterskaber (intertekstuel genealogi) kan bidrage til at afteoretisere konstruktionen og påvise en potentiel genericitet mellem de udvalgte tekster. Den biografiske genealogi, der drejer sig om de menneskelige og venskabelige relationer mellem genrens forfattere, er ikke genreskabende som sådan. Disse relationer tilhører den litterære institution (litteraturhistorien) og bør derfor ikke negligeres i overvejelserne om en genre er en "teoretisk" eller "historisk" konstruktion. I det lyriske epos angår de følgende data nogle af genrens biografiske genealogier. Claudel hævder, at han har overværet Hugos begravelse i I885. Claudel og Saint-John Perse mødtes i Sydfrankrig i 1905, hvorefter de korresponderede jævnligt indtil I950. Ved Claudels død i 1955 skriver Saint-John Perse en hyldest til ham. SaintJohn Perse besøgte Supervielle på en rejse i midten af I920'erne, og i I949 skriver han et brev til Supervielle, hvori han takker for et hyldestdigt, Supervielle har skrevet til ham, og som denne publicerer året efter. Glissant sendte personligt et eksemplar af sine første digte (deriblandt Les Indes) til Saint-John Perse, hvor han i hånden indskrev et bevis på sit "venskab" 
til Saint-John Perse. Senere modtog Saint-John Perse andre værker af Glissant, hvori han noterede sine iagttagelser angående teksten. Disse forhold kan påpege gensidig indflydelse, om end det ikke kan påvises konkret.

\section{Intertekstuel genealogi: Dante}

Den intertekstuelle genealogi er det slægtskabsmønster, som forfatterne skaber mellem hinandens tekster via eksplicitte intertekstuelle henvisninger. Navnlig Claudel hylder tekster inden for det lyriske epos, nemlig Hugos La Légende des siècles og Vents af Saint-John Perse, som han helliger et helt essay. Desuden gør han Péguy (som har skrevet en bog om Victor Hugo) til Hugos arvtager inden for moderne religiøs digtning. Léopold Sédar Senghor har næppe skrevet lyriske eposer. Han wakker dog en kraftig linie mellem Claudel, Péguy og Saint-John Perse, hvis stilarter han imiterer, og han indsætter sig selv i den samme tradition.

Både Hugo, Péguy, Claudel og Saint-John Perse var betagne af Dantes epos Den guddommelige Komedie. Ligesom Victor Hugo i sin tid fik Saint-John Perse i 1965 tildelt den ære at holde åbningstalen til den italienske mindehøjtidelighed for Dantes fødsel, som holdes én gang hvert århundrede. I denne tale beskriver Saint-John Perse Dantes epos som "denne omfattende kommentar til menneskets krønike, som Komediens store episke oversigt udgør" (Saint-John Perse 1982: 454). Dante er Perses store forbillede, men hyldesten kan også betragtes som en poetologisk refleksion over hans eget værk. Når Perse omtaler Dante som en af "de store migrantdigtere" (p. 457), placerer han sig derfor i denne tradition og peger, en smule indiskret, på sig selv som mytisk digterfigur på højde med Dante.

Claudel opfatter også Dante ud fra sin egen poetik, nemlig som en inspireret, klarsynet og katolsk digter (Claudel 1967: 422f). Fra Gud modtager digteren ifølge Claudel en inspiration til at udtrykke "ting af en så omfattende karakter, at kun hele verden er tilstrækkelig for værket". Et epos inkluderer netop denne "omfattende" beskrivelse af verden. Når Claudel forklarer Dantes tekst og samtidig insisterer på dens aktualitet som religiøs tekst $\mathrm{i}$ det 20 . århund- rede, udvider han ligesom Perse sin forståelse for den genre, inden for hvis rammer han selv ønsker at skrive. Claudel skrider endda til samme handling som Hugo, der i La Légende des siècles både skriver en idyl om Dante (Hugo 1950: 503) og en sang, som han mener Dante skulle have medtaget i Den guddommelige Komedie: en dommedagsvision, der tillægger alle menneskehedens dårskaber pavens ansvar. Claudel inkorporerer nemlig en ode til Dante - der i øvrigt er dateret "København I92I" - i Feuilles de saints.

Endelig skal det nævnes, at Péguy i en samtale med sin Lotte ser sin Ève (1913) i samme intertekstuelle optik: "Jeg skriver op mod halvtreds vers hver morgen, undertiden hundrede. 'Eva'! Hvilken titel! Det bliver en ny 1lliade. Jeg siger dig: det bliver endnu større end Dantes 'Paradis'" (Louette 1968: 33).

Digterne til det lyriske epos inspireres af Dante, men ikke af den episke poesi i Frankrig, som af mange betegnes som en fiasko. ${ }^{2}$ Selvom forfatterne via den intertekstuelle genealogi hævder et generisk tilhørsforhold til Dante og dermed frasiger sig den franske tradition, indskriver de sig alligevel i den pga.

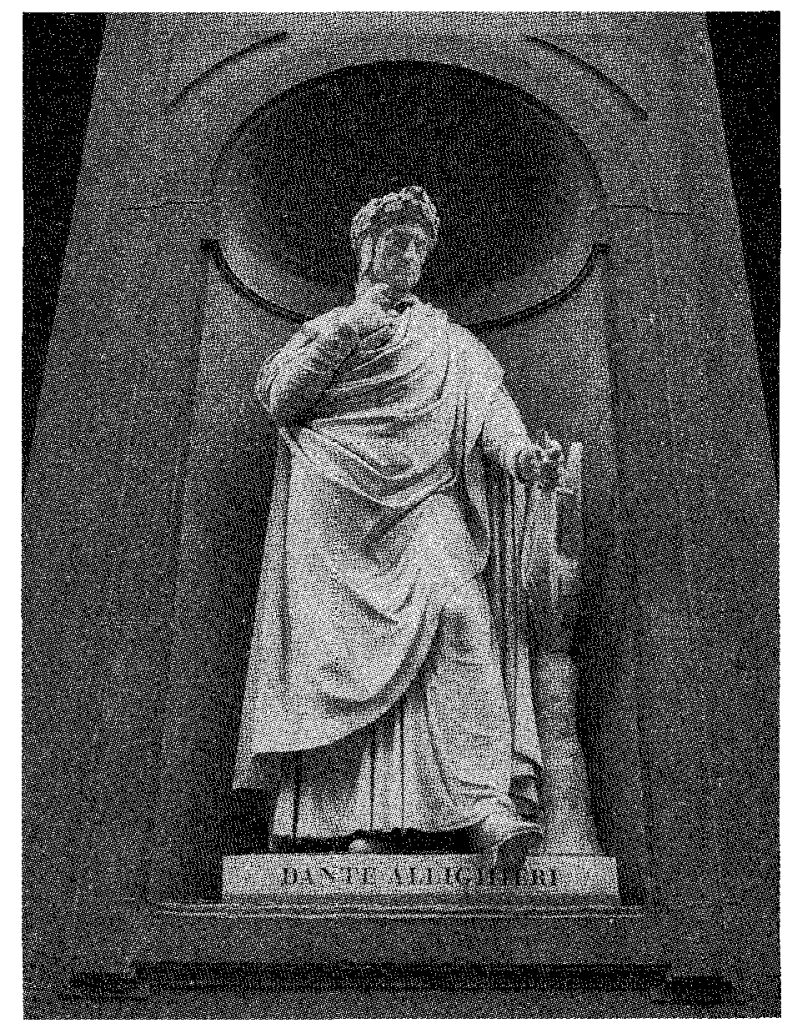


deres stærke franske nationalisme. Set ud fra et litteraturhistorisk perspektiv er det lyriske epos en transformation af det klassiske franske epos.

Sammenholder man den biografiske genealogi med den intertekstuelle genealogi, opstår der mangfoldige sammenhænge både mellem digterne af det lyriske epos og mellem deres tekster. Og sammenholder man yderligere den biografiske og den intertekstuelle genealogi med de tematiske og genrestilistiske træk (transtekstualitet), som analysen har fremdraget, undgår man næppe en fælles genericitet. Det er selve kombinationen af biografi, intertekstualitet og transtekstualitet, der gør det muligt at tale om en genre. Kombinationen af fællestrækkene på så forskellige niveauer bevirker, at genren er tættere på at være en "historisk genre" end en "teoretisk" konstruktion i Todorovs forstand. Det eneste, genren har manglet for at blive "historisk", er en adækvat og konsistent genrebetegnelse, som digterne selv skulle have brugt til at karakterisere deres værk med. Det er derfor nærmest kun i navngivelsesprocessen, at genrekonstruktionen er "teoretisk".

\section{Navngivelse af det lyriske epos (I)}

Såvel digtere som kritikere har forsøgt at genrebestemme flere af de tekster, jeg kalder for lyriske eposer. De har kaldt disse tekster for "små epopéer" (Hugo), "episk digt" eller "epopé" (Claudel 1965: 614, 616), "epos uden helt" (Paulhan 1992: II), "mytisk epos" eller "historisk epos" (Raybaud 2002: I68) og "poetisk epos" (Rigolot 1987: II9). Deres analyser og beskrivelser af genrens tekster er præcise, men problematiske $i$ et generisk perspektiv. Når Carol Rigolot mener, at Sømarker er et "poetisk epos", undlader hun at angive, hvilke andre konkrete værker der kan indgå i genren. De nævnte genrebetegnelser indgår $\mathrm{i}$ studier, der ikke har et generisk sigte, men er rettet mod en teksteller forfatterskabsanalyse. Dette implicerer, at disse genrebetegnelser ofte kun dækker over én eneste tekst, og at teksten dermed på sin vis bliver genreløs (agenerisk). Genrebetegnelserne støtter i de nævnte tilfælde kritikernes forståelse af teksterne - hvilket ikke skal negligeres - men uden at kritikerne konstruerer en egentlig genre med alt, hvad dette indbefatter af tekstanalyse, genrestilistik, biografiske og intertekstuelle genealogier.

\section{Den genreløse tekst: illusion eller realitet?}

Rent teoretisk er der konsensus om, at der ikke findes genreløse tekster. Todorov mener, at "enhver tekstbeskrivelse [...] er en genrebeskrivelse" (Todorov 1970: II), ikke mindst fordi analysesproget ligesom alt andet sprog indeholder generiske kategorier. Schaeffer afviser agenericiteten i og med, at alle tekster enten "integreres" $i$ en specifik genre eller "integrerer" en mangfoldighed af andre genrer i sig (Schaeffer 1986: 204). Enhver tekst har således en genericitet. Derrida tilslutter sig på den ene side den teoretiske ekskludering af agenericiteten, idet han hævder, at "der ikke findes tekster uden genre" (Derrida 1986: 264). På den anden side mener han, at "genrens lov" indeholder en "kontra-lov" (p. 254), som bevirker, at en tekst ikke "tilhører" en genre, men kun "deltager" $i$ en genericitet, som ikke nødvendigvis kan bestemmes som en specifik genre ( $p$. 264). Derrida analyserer en tekst af Blanchot, som skulle bevise denne kontra-lov (at alle tekster modvirker et genretilhørsforhold), men synes at gå så langt som til at hævde, at teksten er genreløs, og at den ophæver selve det generiske. Hertil kunne man som Todorov hævde, at når Derrida beskriver Blanchots tekst, beskriver han også dens genre.

Teoretisk set findes den genreløse tekst næppe, men i praksis taler kritikere (deriblandt Derrida) ofte om tekster uden for kategori. Måske skyldes dette, at mange moderne tekster virker singulære (autonome) og hybride (ubestemmelige), og at der i moderne litteratur er sket en sprængning af hovedgenrernes normer. Men det kunne også skyldes, at den litteraturkritik, der har arvet post-strukturalismens og postmodernismens tankeform, dyrker tanken om den genreløse tekst. 3 Nutidens litteraturkritik forsøger sjældent at betragte moderne litteratur gennem nye genremønstre. Når kritikeren står over for en generisk indetermineret tekst, kaldes den genreløs, så snart den ikke tilhører en allerede navngiven genre. Selvom det $\mathrm{i}$ praksis synes umuligt at genrebestemme alle tekster, legitimerer dette ikke, at man kalder en række tekster for genreløse, fordi $d \epsilon$ 
- som teksterne i genren for det lyriske epos - er uden for den gængse kanon og ikke er "historiske".

Navngivelse af det lyriske epos (II)

For at navngive en genre må man bestemme dens dominerende træk. Navngivelsen må være udtryk for et højt abstraktionsniveau således, at alle genrens tekster dækkes af betegnelsen, selvom diversiteten inden for en given genre kan være stor. De tekster, jeg henregner til det lyriske epos, sprænger rammerne for det klassiske epos, men de vedbliver med at befinde sig inden for dets horisont. Når man kender digternes genrebevidsthed og deres inspirationskilder, er det nærliggende at have termen 'epos' som kernen i genrebetegnelsen. Det episke har stadig sin plads $i$ genren, om end på en moderne, sprængt facon. Imidlertid er det nødvendigt med en term, der udtrykker overskridelsen af det klassiske epos for at korrigere for selve genretransformationen. Betegnelserne 'mytisk' og 'historisk' beskriver ting, som gælder for det lyriske epos, men som på sin vis også kunne gælde for det klassiske epos. 'Uden helt' passer på nogle af teksterne, men 'med mange helte' kunne være lige så dækkende, og prædikatet er for snævert til at omfatte alle genrens tekster. 'Poetisk' er en generel term, der beskriver genretransformationen præcist. Jeg vil dog foreslå termen 'lyrisk', da denne term kan tilføje en betydning, som det neutrale 'poetisk' ikke kan.

Med 'lyrisk' kan man referere til en særlig tradition, lyrismen, der er en tradition, der refererer til Orfeus, der med sin lyre og sang fortryller dyr og mennesker, en tradition, der er forbundet med myten. Ligesom i Orfeusmyten består lyrismen i en særlig attitude, som består $i$ at rette blikket og stemmen mod noget guddommeligt eller sublimt, at hylde kosmos, at sætte poesi lig med sang og musik og at være inspireret midt i sin fortvivlelse. Det lyriske subjekt udspørger sig selv og søger permanent efter identitetsmæssige holdepunkter, fordi det oplever en fragmenteret virkelighed og fremmedgørelse (p. 135, 212). Det er derfor, det benytter sig af udsigelseskonfigurationer som præsentativet. 'Lyrisk' gør på denne måde opmærksom på, at udsigelsen i det lyriske epos er anderledes end i det klassi- ske epos, men understreger samtidig, at eposet stadig er mytisk og beretter mytehistorisk om mennesket $\mathrm{i}$ fortiden, nutiden og fremtiden. Egentlig indeholder det klassiske epos også traditionelle lyriske elementer (gængse symboler, metaforer, metrik, etc.), men kernen i genren er det episke, ikke det lyriske. Modsat genrer som den prosa-poetiske autobiografi og den poetiske kronik, 4 hvor det burleske og det groteske hersker, er det lyriske epos fyldt med patos, uden at det dog for en nutidig læser virker for patetisk. Genren forbliver nemlig modernistisk på grund af $\sin$ poetiske udsigelse med deskriptive metaforer, præsentativer og minimal kohæsion.

\section{Noter}

I. Alle citater i denne artikel er oversat af undertegnede, på nær citaterne fra Saint-John Perses Sømørker (2003).

2. Set med vore dages øjne er den episke poesi i Frankrig en mislykket genre (cf. forordet og noterne i Voltaire, Euvres complètes de Voltaire, t. 2, La Henriade, Genève, Les Délices, 1970, pp. II og 213). Hverken Ronsards La Franciade (1572), Voltaires La Henriade (1728) eller Chateaubriands Les Martyrs (1809) er vellykkede, selvom de fremstår som genrens mest kendte værker og indgår $i$ store forfatterskaber.

3. Et værk som L'Eclatement des genres littéraires au XXe siècle (Dambre \& Gosselin-Noat, 200I, Paris, Presses de la Sorbonne Nouvelle), der samler bidrag fra 26 forskellige forskere, er et godt eksempel. Mange af bidragenes titler angiver en form for dyrkelse af agenericiteten: "hétérogénéité générique", "crise de la fiction", "éclatement du théâtre", "le roman était-il bien son genre?", "Des formes, point de genres ?", "Bon usage et subversion du discours lyrique", "Le surréalisme fait-il du genre?", "le bon genre et les autres", "les genres dans tout leur éclat", "Un 'fatras' inclassable", "la dérive des genres", "le mélange des genres", "la dissolution autobiographique", "violence du genre, genre de violence?", "l'insoutenable indétermination du genre", "une polyphonie des genres" (mine fremhavelser). Jean-Marie Schaeffers indledning i dette værk påpeger denne arv fra postmodernismen (p. II).

4. Cf. undertegnedes artikler "Den prosa-poetiske autobiografi", Passage - tidsskrift for litteratur og kritik, nr. 4I, 2002, pp. 35-47 og "La chronique poétique - esquisse d'un genre littéraire moderne", Revue romane, nr. 39-I, 2004 (i tryk).

Litteratur 


\section{Det lyriske epos}

Alyn, M. (1968), Nuit majeure, Paris, Flammarion. Alyn, M. (2002), Les Alphabets du Feu (Byblos, La Parole planète, Le Scribe errant), s.1., IDLivre.

Aragon, L. (1969), Les Poètes (1960), Paris, Gallimard. Aragon, L. (1963), Le Fou d'Elsa, Paris, Gallimard. Césaire, A. (1956), Cahiers d'un retour au pays natal, Paris, Présence Africaine.

Claudel, P. (1967), Corona benignitatis anni dei (1915), Feuilles de saints (1925), in Euvre poétique, Paris, Gallimard (Pléiade).

Glissant, E. (1994), Les Indes (1955), Le sel noir (1960), in Poèmes complets, Paris, Gallimard.

Hugo, V. (1950), La Légende des siècles (I859), Paris, Gallimard (Pléiade).

Leconte de Lisle, C.-M. (1935), Poèmes barbares (1862), Paris, Alphonse Lemerre.

Péguy, C. (1948), Le mystère des Saints Innocents (1912), La tapisserie de sainte Geneviève et de Jeanne d'Arc (1912), Ève (I9I3), in Euvres poétiques complètes, Paris, Gallimard (Pléiade).

Saint-John Perse (1982), Anabase (1924), Exil (1941), Vents (1946), Amers (1957), in Euvres complètes, Paris, Gallimard (Pléiade).

Saint-John Perse (2003), Sømarker, Århus, Husets Forlag. Supervielle, J. (1996), La fable du monde (1938), Oublieuse mémoire (1948), Paris, Gallimard (Pléiade).

Kritik og anden litteratur

Brunel, P. (2003), Mythopoétique des genres, Paris, PUF. Claudel, P. (1965), Euvres en prose, Paris, Gallimard (Pléiade).

Combe, D. (2002), "La stylistique des genres", Langue française $135:$ 33-49.

Derrida, J. (1986), "La loi du genre”, Parages, Paris, Galilée.

Friedrich, H. (1968), Strukturen $i$ moderne lyrik, Kbh., Arena.

Larbaud, V. (199I), Lettres à Adrienne Monnier et à Sylvia Be- ach, Institut Mémoires de l'édition contemporaine. Louette, H. (1968), Péguy lecteur de Dante, Paris, Cahiers de l'Amitié Charles Péguy

Marinetti, F.T. (I909), Enquête sur le vers libre, Milano, Editions de "Poesia".

Maulpoix, J.-M. (1996), "La quatrième personne du singulier", in D. Rabaté (ed) Figures du sujet lyrique, Paris, PUF.

Maulpoix, J.-M. (2000), Du lyrisme, Paris, José Corti.

Millet, C. (1995), Victor Hugo : La Légende des siècles, Paris, PUF.

Millet, C. (1997), Le légendaire au XIX ${ }^{e}$ siècle : Poésie, $m y$ the, vérité, Paris, PUF.

Paulhan, J. (1992), Enigmes de Perse, Mazamet, Babel.

Rabaté, D. (1996), "Enonciation poétique, énonciation lyrique", in D. Rabaté (ed) Figures du sujet lyrique, Paris, PUF.

Rabatel, A. (200I), "Valeurs énonciative et représentative des "présentatifs" c'est, il $\gamma$ a, voici/voilà: effet point de vue et argumentativité indirecte du récit”, Revue de sémantique et pragmatique 9/10 : 43-74.

Raybaud, A. (2002), "Poésie-banyan, poétique-rhizome : Glissant (Les Indes), le passage par Perse (Vents)", in Eveline Caduc (ed) Postérités de Saint-John Perse, Actes du colloque de Nice 4, 5, et 6 mai 20oo, Faculté des Lettres de Nice.

Rigolot, C. (1987), “Amers - à la recherche d'une poétique du discours épique", La Revue des lettres modernes, Saint-John Perse I.

Said, E. (1995), Orientalism: Western conceptions of the Orient, London, Penguin Books.

Schaeffer, J.-M. (1986), "Du texte au genre", in G. Genette (ed) Théorie des genres, Paris, Seuil.

Segalen, V. (1978), Essai sur l'exotisme : une esthétique du divers, Cognac, Fata Morgana.

Todorov, T. (1970), "Les genres littéraires", Introduction à la littérature fantastique, Paris, Seuil. 